
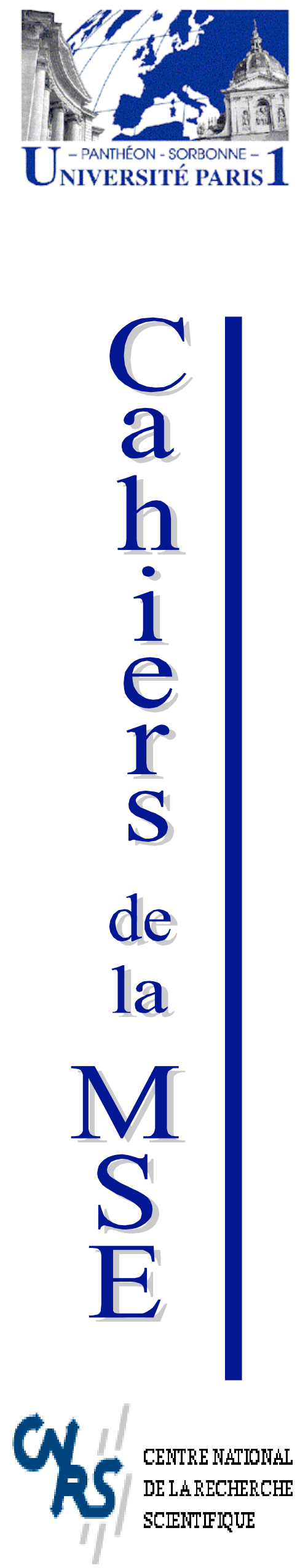

CENTRE NATIONAL

DE LARECHERCHE

SCIENTIFIQUE

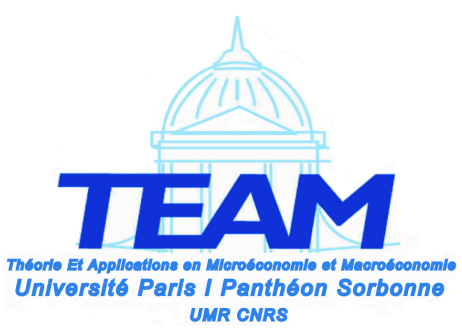

Do banking crises enhance efficiency ? A case study of 1994 Turkish and 1997 Indonesian crises

Julien REYNAUD, TEAM

Rofikoh ROKHIM, TEAM

2005.07 


\title{
Do banking crises enhance efficiency? \\ A case study of 1994 Turkish and 1997 Indonesian Crises ${ }^{1}$
}

\author{
Julien REYNAUD ${ }^{2} \&$ Rofikoh ROKHIM
}

\footnotetext{
${ }^{1}$ We are grateful to Thérèse Chevalier, Jezabel Couppey-Soubeyran, Rodolphe Desbordes, Jérôme Héricourt and Jean Pierre Laffargue for constructive comments. We also thank David Tripe for his helpful report at the EFMS Asia-Pacific Conference 2004. Participants at the GDR \& CEFI, CEPII \& CEPN, CERDI, EFMS, ISEG, TEAM conferences and seminars are gratefully acknowledged. All reminding errors are ours.

2 Corresponding author: TEAM - CNRS, Money-Bank-Finance Group, MSE, 106-112 Bd. de l'Hôpital, 75647 PARIS Cédex 13. E-mail: julien.reynaud@malix.univ-paris1.fr
} 
Resume. Cet article a pour objectif de mettre en relation les concepts d'efficacité et de crise bancaire. Cette mise en parallèle trouve sa justification dans la théorie des cycles économiques selon laquelle une crise est le point de retournement à partir duquel l'économie retrouve une phase de croissance. Théoriquement, les crises bancaires sont censées éliminer les mauvaises banques et de fait permettre au système de fonctionner de manière plus efficace après la crise. Dès lors, si l'efficacité de l'industrie bancaire joue un rôle dans l'apparition de problèmes bancaires, la période d'après crise devrait s'accompagner d'une amélioration de l'efficacité des banques. Nous testons cette hypothèse sur les crises bancaires turque de 1994 et indonésienne de 1997 en utilisant la méthode des frontières stochastiques. Nous trouvons que l'efficacité ne s'améliore pas après la crise, au contraire les banques semblent plus inefficaces.

JEL Classification: G14, G21, G28, G34

Mots clés: crise bancaire, efficacité, Indonésie, Turquie.

\begin{abstract}
Drawing together the concepts of inefficiency and banking crisis is directly inspired by business cycles theory where a crisis is the turning point from which the market/economy is recovering. If inefficiency plays a role in the occurrence of banking crisis, the post-crisis period should be the time for recovering efficiency. Moreover, traditional banking theory predicts that the crisis should eliminate bad banks from the system, leading to a more efficient banking sector. We tested this hypothesis on the 1994 Turkish and 1997 Indonesian banking crises using stochastic cost frontier analysis. Our results show an interesting pattern, opposed to what theory predicts: we find that inefficiency increase after the crises in both banking sectors.
\end{abstract}

Classification JEL: G14, G21, G28, G34

Key words: Banking crisis, Efficiency, Indonesia, Turkey. 


\section{Introduction}

1990s financial crises led economists to rethink completely their approach toward monetary and banking crises (see the survey by Cartapanis, 2002). The International Monetary Funds (IMF, 1998) emphasized that between 1985 and 1995, more than 130 of its members experienced serious banking problems. The 1980s financial markets liberalization in emerging countries is generally blamed as a significant source of instability (Edwards and Mishkin, 1995; Griffith-Jones, 1998; Scialom, 2004). Therefore, inefficiency may be consequently one of the major causes of 1990s banking problems, and should be a concern for policy makers (Resti, 1997). Indeed, inefficiency can be regarded as socially beneficial as it reduces the cost of financial intermediation for consumers (Matthews and Tripe, 2004). Thus greater amount, at better price and quality, are intermediated from savers to producers, enhancing investment and offering greater safety and returns for shareholders (Berger, Hunter and Timme, 1993).

The purpose of this paper is therefore to asses whether a banking crisis can improve banking sector's efficiency? Our point comes from business cycles theory, where a crisis is the turning point from which the market/economy is recovering. In that spirit, if inefficiency plays a role in the occurrence of banking problems, the post-crisis period should be the time of recovering, as bad banks should have been taken over the market. Consequently, we also investigate the idea that efficiency should increase during the period following the crisis. To test this hypothesis, we look at the 1994 Turkish and 1997 Indonesian crises.

The remainder of the paper is organized as follows: Section II defines both concepts of banking crisis and efficiency, and asses the interaction between the two in the cases of Indonesia and Turkey. Section III presents the sample and the econometric methodology. Section IV describes and analyzes the results. Section $\mathrm{V}$ concludes and offers some policy recommendations. 


\section{The role of efficiency in banking crises}

\subsection{Banking crises}

While each banking crisis has its own dynamics, most of the main components remain identical. These common causes have been pointed out by Calomiris and Gorton (1991), and for the special case of emerging economies by Goldstein and Turner (1996). They listed the possible causes for banking crises as follow: (i) Both external and domestic macroeconomic volatility, (ii) Lending booms, asset price collapses and surges in capital inflows, (iii) Increasing bank liabilities with large maturity/currency mismatches, (iv) Inadequate preparation for financial liberalization, (v) Heavy government involvement and loose controls on connected lending, (vi) Weaknesses in the accounting, disclosure and legal framework, (vii) Distorted incentives for bank owners, managers, bank depositors and supervisors, (viii) Exchange rate regimes. The last 20 years exhibited one common feature: financial liberalization and more precisely the difficulties faced by banks in a global banking market (Edwards and Mishkin, 1995; Griffith-Jones, 1998; Scialom, 2004).

Building on these elements, banking crises can be divided into two categories: microeconomic and macroeconomic. Our study focuses on the microeconomic level so the macro level will only be shortly presented, before turning to our point.

The macroeconomic level refers to a bad operating environment. Banking crises can arise from macroeconomic problems, the latter being external to the banking system. Even well-run banking systems operating in a strong legal and regulatory framework can be hit by an unstable macroeconomic environment. The literature revealed a lot of macro problems that can be sources of banking crisis: lending booms, possibly fuelled by excessive capital inflows or changes in tax rules, real estate and/or equity price bubbles, business downturns, growing excess capacity/falling profitability in real sector, rising fiscal and/or 
current account deficits, weakened public debt sustainability, sharp changes in exchange rates and real interest rates, etc.

The microeconomic level refers to bad banking. Banking crises are often linked to weak bank operations: poor lending practices, excessive risk taking, deficient governance, lack of internal controls, focus on market share rather than profitability, and currency and maturity mismatches in the banks themselves or among their borrowers. In some emerging countries, these conditions may be worsened when bank ownership is very narrow. In these circumstances, bad banking refers mostly to bad lending, connected lending, insider operations, and outright fraud may go hand in hand with impunity. Similarly, state banks may be run as quasi-fiscal agencies based on political criteria with disregard for commercial principles, undermining their solvency and the soundness of other better-run banks. Bad banking can only persist in the absence of proper regulation and supervision, and of adequate market discipline. Supervisors may also lack authority and the sufficient skilled staff. Expectation of depositors and creditors bailouts is also a well-known source of moral hazard problems that distort incentives, and thus efficiency.

Finally, the distinction between macro- and micro-founded banking crisis can be sometime uneasy. Financial liberalization can be classified in both categories as it influences banks managers and government behaviour and interact between them. In other words, government liberalise banking markets without adapting the legal framework (macro), inducing a distortion of banks' owners and managers incentives (micro).

Banks efficiency should be a serious concern for policy makers. First because the banking industry "has been obsessed with efficiency over the last decade" (Klinkerman, 2003). Second because banking crises can be very costly (table 1), depending mostly on the way public authorities manage it. Conventional academic wisdom acknowledges that a banking authority with a strong budget constraint will solve a banking crisis more quickly than a soft 
budget constrained authority ${ }^{3}$. It has been theoretically shown that a soft budget constraint induces no discrimination between 'good-efficient' and 'badinefficient' banks when bailing out the sector. At the opposite, a strong budget constraint induces that the authority to close the banks. Therefore, recovering time will vary in this respect. An interesting and surprising result can be found in the IMF 1998's World Economic Outlook: emerging economies are more likely to be affected by banking problems than industrialised ones, but the average recovering delay is greater in industrialised countries (table 2).

Table 1: Budgetary cost of banking crises

Table 2: Banking crises and average recovering delay

\subsection{Efficiency}

Coelli, Rao and Battese (1998) summarise conceptual and measurement problems induced by the concept of operating efficiency inspired by the work of Farrell (1957) which defines it as cost minimising and profit maximising production process. Economic efficiency arises from technical and allocative efficiency. The former refers to an over-utilisation of some inputs and the latter refers to a bad combination of inputs comparing to their relative prices. Addressing this problem in emerging markets allows us to refer to the concept of efficiency as typically in these economies, credit is overproduced and personal, capital and funds are badly used to produce it for the reasons listed before.

The way we asses efficiency is generally represented by some form of parametric and non-parametric frontiers. Firms' efficiency is then defined in terms of their relative distance from the efficient frontier which becomes therefore the benchmark for optimum performance. Many comprehensive studies raised important problematic regarding banks operations. Banking efficiency literature in the United States, European Countries and also Eastern

${ }^{3}$ For a stylised model, see Huang and Xu (2000). 
European Countries provided a substantial number of studies with different methodologies. Some researches dealing with efficiency in US Banking found that banks could cut their cost and improve their profit efficiency more by reducing frontier inefficiencies rather than by reducing some optimal level of scale and scope economies to minimize average cost and profit efficiency (Berger and Humphrey, 1991 and 1997, Berger and Mester, 1997). Still working on US banks, DeYoung and Nolle (1996) found that foreign banks are relatively less efficient than domestic banks. Other studies, like Turati (2001), noted that the higher the cost efficiency, the higher the level of profits a bank will earn. He did not found, over 250 European commercial banks from 1992 to 1999, any striking difference in average efficiency among European countries. Sheldon (1999) used unconsolidated data for 1,783 commercial and savings banks in the EU, Norway, and Switzerland for the period 1993-1997 and finds that larger banks, specialized banks and retail banks are more cost and profit efficient than small banks, diversified banks and wholesale banks, respectively. Using Turkish banks, Jackson et al. (1998) found that competition among banks is important for the banking performance and efficiency. Relying on these results, some authors assumed that banks across different countries access equally to the same banking technology. Others concluded that efficiency results can not be compared across borders because each country has specific features, such as regulatory powers, demography, and economic conditions (Bos \& Schimiedel, 2003).

All these studies raised concerns about important features of the production process and economic problematic, but few have investigated the implication of inefficiency on banking crises.

\subsection{Banking crises in Indonesia and Turkey}

Both Turkish and Indonesian States were strongly involved in the financial sector management, until the end of the 70 s for Turkey and the 80 s for Indonesia. Policymakers relied mainly on imports-substitution strategies. Such policies aimed at ensuring countries self-sufficiency, by the means of protection against international competition, including protection of the 
banking industry. After the 80s oil crashes, the development strategies changed for these countries, turning to promote exports and financial markets liberalization.

The International Monetary Funds (IMF) stabilisation programs imposed Turkish financial sector liberalisation. Following the financial crisis of the late 1970 s, the program aimed at increasing the rate of saving and channelling resources towards more efficient activities. This program was designed to constrain banking sector to fund country's development. Banks developed their structures, bought many financial institutions, as well as investment banks. In a similar way, Indonesian financial liberalization initiated on June 1983 led to the suppression of interest rate controls and credit ceilings for banks, thus lifting legal lending limit. The purpose was to convert the financial framework from a state dominated system into a market based one. However, the insufficient regulatory frame was unable to control the destabilising effects of markets opening. Indeed, these deregulations did not train long term capital inflows (i.e. FDI) as shown in figure 1. In 2000, Turkey was ranked $52^{\text {nd }}$ row among the countries recipient of FDI. Indonesia was in an even worse situation following the UNCTAD report, during 1999-2001, with the $138^{\text {th }}$ position. Banks were therefore forced to fund them elsewhere, improving competition and risk behaviour (i.e. liquid/speculative funds).

Figure 1: Foreign direct investment, net inflows (\% of GDP)

The liberalization process led both countries to some structural weaknesses listed below.

\section{Insufficient capitalisation}

Stockholders' equity remained low because law made it possible to open a bank with little funds, from approximately US\$30 millions for Turkey. In Indonesia, the deregulation of October 1988, made possible to create a new bank with even lower capital (only 10 milliard Rupiah, i.e. around US\$ 4 millions). Moreover, taxes and chronic hyperinflation in those countries did not 
encourage banks-owners to increase their own capital stocks. Figure 2 highlights the weakness of owned capital stocks in both Turkish and Indonesian systems.

Figure 2: Net Working Capital/Total Assets

\section{Degradation of credits quality}

The credits quality decreased because of illegal appropriations, concentration of risks and insufficient provisions. Figure 3 emphasises banking assets weakness. The bad credits quality is even more obvious when considering the ratio of unproductive loans. To offset their losses, banks artificially increased the value of their underperforming assets (by making calculation with bookand not market-values for example), in order to meet prudential ratios.

Figure 3: Permanent assets (PA)/ Total assets and Non-performing loans (NPL)/Total loans

\section{A large exposure}

Financial liberalization led banks in both countries to large exchange and interest rates exposures (FX open positions, maturity mismatch) involving a volatile and limited profitability. Undoubtedly, mismanagement is to be held as responsible, as well as banking authorities. Maturity mismatch made the sector more vulnerable to liquidity shocks, just like the FX open positions weakened the sector vis-à-vis the external shocks. Figures 4 and 5 respectively show liquidity levels and losses trained by FX open positions.

Figure 4: Liquid assets/Total assets (\%)

Figure 5: Interests expenses/Non-interests expenses (\%)

In terms of returns over equity (RoE) and over assets (RoA), Turkish banks look less more profitable than foreign banks. In Indonesia, state-owned banks were very unprofitable and even private- and foreign-owned banks seem to 
have suffered during the second half of the 1990s. Table 3 shows all the details. On the overall, state-owned banks are less profitable, which is not surprising.

Table 3: $\mathrm{RoE} / \mathrm{Ro} A$ ratios

\section{Small sizes and fragmented structures}

After having passed from 43 banks in 1980 to 66 in 1990, the banking sector counted 79 banks in 2000. On the 74 active banks in 2000 (5 were put under supervision of the Funds of Guaranteed Saving and Deposits, TMSF), 56 are deposit banks, the remaining 18 being banks of investment. Among the deposit banks, 4 are stat-owned, 26 are Turkish banks, 18 are foreign-owned and 8 are under supervision of the TMSF. For Indonesia, before 1990, banks were dominated by the State and big private banks. Based on October 1988deregulation, private and foreign banks accessed the market easily. Table 4 shows the fragmentation of banking sector structure for both countries.

Table 4: Structure banking sectors 1990/2000

\section{Inadequate supervision}

Banking sectors are characterized by both an internal and external inadequate supervision, due mainly to the lack of transparency. The Turkish banks used to window-dress their balance sheets, either using accountancy tricks in overestimating the value of the permanent credits compared to their market prices, or quite simply by playing with the inflation and exchange rates.

In Indonesia, the lack of supervision trained a sharp increase of underperforming credits. The economic crisis showed that banks were vulnerable mainly because of high NPLs. Because of inadequate supervision, only little banks declared their real NPL positions, especially because of the lack of legal sanctions from monetary authorities.

On the overall, both banking sectors were dominated by the States. The liberalizations have weakened banking industries, worsening bad banking 
behaviours. Thus, coming to our hypothesis, we expect an increase of inefficiency before and a decrease after the crisis. ${ }^{4}$

\section{Methodology}

There are five ways to asses efficiency; two non-parametric approaches: data envelopment analysis (DEA) and free disposal hull (FDH); and three parametric estimation methods: stochastic frontier analysis (SFA), free distribution analysis (DFA) and thick frontier analysis (TFA).

We build a translogarythmic cost function to estimate a stochastic cost frontier (SFA) for each of our panel using log-Likelihood estimation. The use of a cost instead of a production function is due to the assumption that banks in Indonesia and Turkey were strictly following profit maximization strategies, which can not be robustly satisfied during the sample period. Moreover, because of Governments' soft budgets constraints, outputs levels could have been exogenously driven. These assumptions lead us to reject a production approach. A cost function was preferred under the assumptions of exogenous output and input prices. The competitiveness of banking industry for both countries suggests that banks competed for their input price and not only on output side. Finally, a cost function allows us to consider more than a unique output. We introduce the inputs/outputs choice in the next section.

Largely used in related literature, the translog cost function surpasses other functions (like Cobb-Douglas, CES, Leontieff, etc.) thanks to its flexible form. The use of the SFA method is mainly motivated by the fact that nonparametric approaches do not consider noise in the estimation. The fact that we are actually looking at emerging economies means a more unstable economic environment and idiosyncratic shocks can not be omitted.

\footnotetext{
${ }^{4}$ We did not account for pure 'sun spots' crisis. Both banking crises showed strong structural components and it has never been argued, to our best knowledge, that Indonesian and Turkish crises were due to 'sun spots'. See Bhattacharya and Jacklin (1998) for a more formal distinction.
} 
Moreover, it has been shown that SFA method is more robust for bigger samples (Coelli, Rao and Battese, 1998). ${ }^{5}$

The benchmark equation can then be represented as follows (usual restrictions apply):

$$
\begin{aligned}
\ln \left(t c_{i t}\right)= & \alpha_{0}+\sum_{j=1}^{3} \alpha_{j} \ln \left(w_{i t j}\right)+\sum_{k=1}^{2} \beta_{k} \ln \left(y_{i t k}\right)+\frac{1}{2} \sum_{j=1}^{3} \sum_{l=1}^{3} \alpha_{j l} \ln \left(w_{i t j}\right) \ln \left(w_{i t l}\right) \\
& +\frac{1}{2} \sum_{k=1}^{2} \sum_{m=1}^{2} \beta_{k m} \ln \left(y_{i t k}\right) \ln \left(y_{i t m}\right)+\sum_{j=1}^{3} \sum_{k=1}^{2} \delta_{j k} \ln \left(w_{i t j}\right) \ln \left(y_{i t k}\right)+\varepsilon_{i t}
\end{aligned}
$$

where, for the $i^{\text {th }}$ panel of banks at time $t,\left(w_{i t j}\right)$ are the price of inputs, $\left(y_{i t k}\right)$ the outputs, $\left(t c_{i t}\right)$ the total cost and $\alpha_{0}, \alpha_{j}, \beta_{k}, \alpha_{j l}, \beta_{k m}$ and $\delta_{j k}$ the parameters to be estimated. $\varepsilon_{i t}$, the disturbance term of the model, is assumed to have two components:

$$
\varepsilon_{i t}=v_{i t}+\mu_{i t}
$$

where, $v_{i t}$ is the idiosyncratic error and $\mu_{i t}$ is a time-varying truncated-normal random variable which reflects the distance of observations from the cost frontier, i.e. the inefficiency term to be estimated. These terms are distributed independently of each other and defined as follows:

$$
\mu_{i} \text { is iid on } N^{+}\left(\mu, \sigma_{\mu}^{2}\right)
$$

and

$$
v_{i} \text { is iid on } N\left(0, \sigma_{v}^{2}\right)
$$

with

$$
\mu_{i t}=\exp \left\{-\eta\left(t-T_{i}\right)\right\} \mu_{i}
$$

${ }^{5}$ See Aigner et al (1977), Berger and Mester (1997), Guarda and Roubah (1999), Turati (2001), Bonin et al (2003) for extensive discussions about the SFA method. 
where, $\eta$ is the decay parameter with $T_{i}$ the last time period in the $i^{\text {th }}$ panel. When $\eta>0$, the degree of inefficiency is decreasing over time. When $\eta<0$, the degree of inefficiency is increasing over time. We use a time varying model instead of a time invariant one to estimate the evolution of the inefficiency over the period. We also computed time invariant models to enforce our results and found same patterns. ${ }^{6}$

\section{Data and model specification}

The overall sample includes 200 banks: 143 banks from Indonesia and 57 from Turkey. We divided the panel in two sub-panels: Panel A for the pre-crisis time and Panel B for the post-crisis period. Then, we differentiate the banking sector in three groups according to their state, private and foreign ownerships. We also build another sub-panel discriminating between large and small banks, taking respectively the highest and the smallest quartiles in term of bank's assets to total assets. For each sub-panels, two models are estimated: a Precrisis model using Panel A and a Post-crisis model using Panel B. For Indonesia, Pre-crisis period is 1991 to 1996 and Post-crisis period is from 1998 to 2001. For Turkey, the Pre-crisis begin in 1990 and finishes in 1993. The Post-crisis period start in 1995 and ends in 1999. We decided not to take into account the year of crisis because of too much macro- and micro-economics instability (strong currencies depreciation, persistently high interest rate volatility, etc), therefore Indonesia 1997, and Turkey 1994 are excluded from the panel.

For Indonesia, the data come from PT Ecofin and from announcement of annual financial statements which are published in Bisnis Indonesia Daily. For Turkey, the data come from the Banks Association of Turkey Periodical Reports: Banks in Turkey, 1997 (for the 1990-1996 periods) and Banks in Turkey, 2001 (for the 1997-1999 periods).

\footnotetext{
${ }^{6}$ These results are available upon request to the authors.
} 
Table 5 introduces the variables used. Table 6 shows the repartition of banks inside the different panels, showing that the Indonesian and the Turkish banking sector are similarly built, strengthening the relevance of these countries for our study.

Table 5: Distribution of sample banks by category

Table 6: Description of variables

The total cost $\left(t c_{i t}\right)$ is the sum of interest and non interest expenses. There are two outputs $\left(y_{i t k}\right):\left(y_{i t 1}\right)$ representing the total credits of the type of banks $i$, and $\left(y_{i t 2}\right)$ regrouping all the others productive assets (the essential part is made of cash and securities). There are three input prices $\left(w_{i t j}\right):\left(w_{i t 1}\right)$ is the price of labour, measured by the ratio of total salaries and employee benefit expenses to total assets (since the information with respect to the number of employees is almost completely lacking for most Indonesian banks, we are not able to compute the personnel expenses per employees, alternatively, the personnel expenses as a fraction of total assets is used); $\left(w_{i t 2}\right)$ is the price of physical capital, measured by the ratio of total non interest expenses minus total salaries and employee benefit expenses over total fixed assets; and finally, $\left(w_{i t 3}\right)$ is the price of borrowed funds, measured as the total interest expenses over total fund borrowed, mainly made of deposits (demand and term) and trading account securities.

Debate about what constitutes the outputs and inputs in a banking firm is still ongoing. In this paper, the intermediation approach is adopted. The bank uses labour, physical capital and borrowed funds to produce earning assets (see Sealey and Lindley, 1997). This is the most commonly used approach in the bank cost function literature. It is also argued that deposits are an input to the 
production of loans, or alternatively, that they are considered as an output because they involved the creation of added value (Berger, Handcock and Humprey, 1993). We decide to use them as an input referring to conventional accountancy principles ${ }^{7}$ that put them on the liability side.

\section{Results and interpretation}

We focus our work on the variation of the estimated parameters before and after the crisis. To support this choice, we run a Chow-type likelihood-ratio test (results are reported in table 7) pooling together both samples before and after the crisis and comparing them. Both results are positive and enforce thus our estimations. This will help us to estimate the influence of a banking crisis on banks' efficiency. We presume that during a banking crisis, 'bad banks' should be eliminated, leading therefore to an increase in efficiency.

Table 7: LR-tests for both countries

Tables 8 and 9 report the results of the estimated parameters. On the overall, parameters are reasonably consistent with expectations. In most cases, the specifications of the factors (inputs and outputs) turned to be statistically significant for all groups (state, private and foreign banks) and panels (before and after the banking crisis). ${ }^{8}$

Our interpretations focus on table 8 that shows the $\mu_{i t}$ for all specifications. On the whole, the expected positive effects of crises on each country's global banking sector are unexpected. For all sub-samples, i.e. for all type of ownership, and for both countries, the inefficiency is not decreasing after the crisis, and more surprisingly, it seems to increase in most of the cases.

\footnotetext{
${ }^{7}$ Our data come from Balance Sheets so accountancy principles have to be applied. ${ }^{8}$ Factor tables are not reported because our study focuses on the inefficiency term. All the results can be sent on request to the authors.
} 
Looking at the models, small samples and in particular the sub-samples B (i.e. before the crises) fit poorly and did not allow us to compare before and after the crisis results. However, results for the sector and for private (both domestic and foreign owned) banks allows the comparison. Thus we are able to distinguish from the sub-sample B if the sectors' inefficiency is driven by private-domestic-foreign or state-owned banks. Not surprisingly, overall inefficiency is driven by state-owned banks. ${ }^{9}$ For both countries, privatedomestic banks are more inefficient than private-foreign owned banks. This result in also in contradiction with the literature that call for a Foreign-OwnedBank Barriers Hypothesis that did not seems to apply to both countries (see Berger, De Young, Genay and Udell, 2000, for a review of this hypothesis). This can be explained by the fact that this hypothesis applies for developing countries. The focus on emerging economies can explain our results, meaning that foreign banks are well run and beneficiate from know-how and from high skilled and experienced personnel, leading thus to more efficient work.

\section{Table 8: Inefficiency scores for samples $A$ \& $B$}

Lastly, looking at the size effect, table 9 shows an interesting pattern. If large banks seem to be more inefficient on the overall (inefficiency scores are higher for large banks in both countries), the crisis affects countries differently. Turkish large banks' inefficiency decreases after the crisis and small banks' inefficiency increases after the crisis. In other words, it means that even if large banks are less efficient, small ones are not better of after the crisis. For Indonesia, results are reversed. Inefficiency is slightly increasing for large banks after the crisis, and strongly decreasing for small banks. This can be explained by the fact that policy responses by Indonesian and Turkish authorities were different and this may have impact banks differently.

\footnotetext{
${ }^{9}$ Note that for sub-sample B of state-owned Indonesia banks, the estimation reveals a negative $\mu$, meaning that the model does not fit for this sub-sample. On the overall, the model fits better Turkish banking industry. This may be imputable to the recapitalisation and restructuring process, and thus can lead to misinterpretation of the function
} 
Table 9: Inefficiency scores for size samples

\section{Summary and policy recommendations}

This study investigates the cost structure of Indonesian and Turkish banking industries using a translog cost function to build a stochastic frontier before and after the respective banking crises.

Concerning Turkey, our results are consistent with the findings of Yeldan (2001), the Banks Association of Turkey (2000) and the Turkish Banking Regulation: efficiency did not rise after the crisis. Moreover, inefficiency seems to have increase after the crisis. Two major reasons can be suggested: (i) the restructuring program seems to have not been properly managed, and (ii) the macro-economic environment did not fully recover after the crisis. Finally, our findings can be easily linked to the more recent 2000/2001 banking collapse. The Indonesian banking sector is also less efficient in the post-crisis period, which is also consistent with Levin (1996) and McFadden (1994)

Our major insight is that inefficiency did not decrease significantly after the crisis; conversely, it increases after the crisis. To support this conclusion, the International Monetary Funds has published, in 1998's World Economic Outlook, a survey showing that Emerging Markets need on average 2.8 years to recover - in terms of output growth - from a banking crisis. For Turkey, the post-crisis period asked 6 years. For Indonesia, the period after the crisis takes only 4 years. This leads us to recommend prudence for Indonesia's banking sector. If it has not dealt with its inefficiency problems, the sector can be vulnerable to another banking crisis. 


\section{References}

Aigner, D.J., C.A.K. Lovell and P. Schmidt, 1977. Formulation and estimation if stochastic frontier production function models, Journal of Econometrics.

Banks Association of Turkey, 2000. The Turkish Banking System 1958-97, Banks Association of Turkey.

Banking Regulation and Supervision Agency, 2001. Toward a Sound Turkish Banking Sector, Banking Regulation and Supervision Agency.

Bhattacharya, S. and C. Jacklin, 1988. Distinguish Panics and Informationbased Bank Runs: Welfare and Policy Implications, Journal of Political Economy 96.

Berger, A. N. and D.B. Humphrey, 1991. The dominance of inefficiencies over scale and product mix economies in banking, Journal of Monetary Economics 29.

Berger, A.N., D. Hancock and D.B. Humprey, 1993. Bank efficiency derived from the profit function, Journal of Banking and Finance 17.

Berger, A.N., W.C. Hunter and S.G. Timme, 1993. The efficiency of financial institutions: A review of research past, present, and future, Journal of Banking and Finance 18.

Berger, A.N. and L.J. Mester, 1997. Inside the Black Box: What explains differences in the efficiencies of financial institutions, Journal of Banking and Finance 21.

Berger, A. N.; W. C. Hunter and S. G. Timme, 1993. The efficiency of financial institutions: a review and preview of research past, present and future. Journal of Banking and Finance 17. 
Berger, A.N., D.B. Humphrey, 1997. Efficiency of Financial institutions: International survey and directions for the future research, European Journal of Operation Research 98.

Berger, A.N. and R. de Young, 1997. Problem loans and cost efficiency in commercial banks, Journal of Banking and Finance 21.

Berger, A.N., Robert de Young, and G.F. Udell. 2000. Globalization of financial institutions: Evidence from cross-border banking performance, Brooking-Wharton Papers on Financial Services 3.

Bonin, J.P., I. Hasan ann P. Wachel, 2003. Bank performance, efficiency and ownership in transition countries, Working Papers on Banking and the Financial Sector in Transition and Emerging Market economies.

Bos, J.W.B. and H. Schmiedel, 2003. Comparing efficiency in European Banking: a Meta Frontier Approach, Research Supervision 57.

Cartapanis, A., 2002. Le déclenchement des crises de changes : qu'avons-nous appris depuis dix ans?, Economie Internationale, La Revue du CEPII.

Coelli, T., Rao, D.S. P., Battese, G.E., 1998. An introduction to efficiency and productivity analysis, Boston, Kluwer Academic Publishers.

De Young, R and D.E. Nolle, 1996. Foreign-Owned Banks in the US: Earning Market Share or Buying itt?, Journal of Money, Credit and Banking 28 (3).

Edwards, F. and F. Mishkin, 1995. The Decline of Traditional Banking: Implications for Financial Stability and Regulatory Policy, Federal Reserve Bank of New York, Economic Policy Review. 
Farrell, M. J., 1957. The Measurement of Productive Efficiency, Journal of the Royal Statistical Society, Series A 120.

Griffith-Jones, S., 1998. Stabilizing Capital Flows to Developing Countries, Conference on the East Asia crisis, Institue of Development Studies, Brighton.

Guarda, P. and A. Rouabah, 1999. Efficacité et performance des banques en Europe: une analyse stochastique frontière sur des données en panel, Working Paper99-5, Cellule Recherche en Economie Appliquée CRP-Gabriel Lipplan Luxembourg.

Hasan,I. and K. Marton, 2000. Development and efficiency of the banking sector in a transitional economy: Hungarian experience, Working Paper, Institute for Economies in Transition, Bank of Finland.

Huang, H. and C. Xu, 2000. Financial Institutions, Financial Contagion and Financial Crises, IMF, Working Paper 00/92.

International Monetray Funds, World Economic Outlook, May 1998.

Jackson, P.M., Meryem Duygun Fethi and G. Inal. 1998. Efficiency and productivity growth in Turkish commercial banking sector: A non-parametric approach, Working Paper, Management Centre, University of Leicester.

Levine, R., 1996. Foreign banks, financial development, and economic growth, in Claude E. Barfied, ed., International Financial Markets, Washington D.C., AEI Press.

Lindley, J. and C.W. Sealey, 1977. Inputs, outputs and theory of production and cost as depository financial institutions, Journal of Finance, Vol. 2, No: 4.

Mc Fadden, C., 1994. Foreign banks in Australia, The World Bank, Mimeo. 
Matthews, C. D. and D. W. L. Tripe, 2002. Problems in Promoting Efficient Banking Services in a Developing Country - the Case of Papua New Guinea. Paper presented at 2nd International Conference of Banking and Finance at Crete, Greece (9-11 August2002), mimeo.

Pastor, J.M., F. Pérez and J. Quesada, 1997. Efficiency analysis in Banking Firms: An international comparison, European Journal of Operational Research, 98.

Resti, A., 1997. Evaluating the cost-efficiency of the Italian banking system: what can be learned from the joint application of parametric and nonparametric techniques. Journal of Banking and Finance. 21.

Scialom, L., 2004. Economie bancaire, Editions Repères.

Sheldon, G., 1999. Costs, Competitiveness and the changing structure of European banking, Fondation Banque de France pour la Recherche, Working Paper.

Turati, G., 2001. Cost efficiency and profitability in European commercial banking, Instituto di Economia e Finanza, Università Cattolica del S. Cuore, Working Paper.

Yeldan, E., 2001. On the IMF-Directed Disinflation Program in Turkey: A Program For Stabilization and Austerity Or A Recipe For Impoverishment and Financial Chaos?, University of Bilkent, Tureky, mimeo. 
APPENDIX

Table 1: Budgetary cost of banking crises

Source: IMF, Worl Outlook, May 1998

\begin{tabular}{l|c|c}
\hline \multicolumn{1}{c|}{ Country } & Year & $\begin{array}{c}\text { Budgetary cost and quasi- } \\
\text { budgetary cost }(\% \text { of GDP) }\end{array}$ \\
\hline Argentine & $1980 / 82,1985$ & $13-55, \ldots$ \\
Brasil & $1994 / 96$ & $4-10$ \\
Chili & $1981 / 85$ & $19-41$ \\
Colombia & $1982 / 87$ & $5-6$ \\
Spain & $1977 / 85$ & $15-17$ \\
United States & $1984 / 91$ & $5-7$ \\
Finlande & $1991 / 93$ & $8-10$ \\
Indonesia & 1994 & 2 \\
Japan & $1990 \mathrm{~s}$ & 3 \\
Malaisia & $1985 / 88$ & 5 \\
Mexico & $1994 / 95$ & $12-15$ \\
Norway & $1988 / 92$ & 4 \\
Philippines & $1981 / 87$ & $3-4$ \\
Sri Lanka & $1989 / 93$ & 9 \\
Sweden & $1991 / 93$ & $4-5$ \\
Thailande & $1983 / 87$ & 1 \\
Turkey & $1982 / 85$ & 3 \\
Uruguay & $1981 / 84$ & 31 \\
Venezuela & $1980 / 83,1994 / 95$ & $\ldots, 17$ \\
\hline & &
\end{tabular}


Table 2: Banking crises and average recovering delay

Source: IMF, Worl Outlook, May 1998

\begin{tabular}{c|c|c}
\hline & $\begin{array}{c}\text { Number of } \\
\text { crises }\end{array}$ & $\begin{array}{c}\text { Average recovering delay } \\
\text { (years) }\end{array}$ \\
\hline Banking crises & 54 & 3,1 \\
in emerging economy & 42 & 2,8 \\
in industrialised economy & 12 & 4,1 \\
\hline
\end{tabular}


Table 3: $\mathrm{RoE}$ and $\mathrm{Ro} A$ ratios (\%)

Source: TBB (Turkey) and Ecofin and Indonesian Banking Directory (Indonesia)

\begin{tabular}{l|c|c|c|c|c|c|c}
\hline \multicolumn{2}{c|}{} & \multicolumn{2}{c|}{ State-owned } & \multicolumn{2}{c|}{ Private-owned } & \multicolumn{2}{c}{ Foreign-owned } \\
\cline { 3 - 8 } \multicolumn{2}{c|}{} & $1991-1995$ & $1996-2000$ & $1991-1995$ & $1996-2000$ & $1991-1995$ & $1996-2000$ \\
\hline \multirow{2}{*}{ RoE } & Turkey & 0,96 & 0,54 & 3,24 & 3,74 & 6,03 & 4,92 \\
\cline { 2 - 8 } & Indonesia & $-1,3$ & $-0,52$ & 3,06 & $-0,68$ & 2,35 & $-0,61$ \\
\hline \multirow{2}{*}{ RoA } & Turkey & 19,82 & 13,50 & 43,19 & 48,45 & 78,62 & 68,67 \\
\cline { 2 - 8 } & Indonesia & $-20,73$ & 3,47 & 11,99 & $-12,41$ & 19,01 & 89,65 \\
\hline
\end{tabular}


Table 4: Structure of Turkish banking sectors 1990/2000

Source : BDDK (Turkey) and Ecofin and Indonesian Banking Directory (Indonesia)

\begin{tabular}{c|c|c|c|c}
\hline & \multicolumn{2}{|c|}{1990} & \multicolumn{2}{c}{2000} \\
\cline { 2 - 5 } & Indonesia & Turkey & Indonesia & Turkey \\
\hline Number of banks & 143 & 66 & 151 & 79 \\
Number of branches & 166 & 6,560 & 2314 & 7,837 \\
Nombre of ATM & - & 3,209 & 5765 & 11,991 \\
Number of employees & - & 154,089 & - & 170,401 \\
\hline
\end{tabular}


Table 5: Distribution of sample banks by category

Source: TBB (Turkey) and Ecofin and Indonesian Banking Directory (Indonesia)

\begin{tabular}{c|r|c|c}
\hline Code & Category & Indonesia & Turkey \\
\hline 1 & Public banks & 31 & 12 \\
\hline & $\%$ & 21.7 & 21.1 \\
\hline 2 & Private banks & 78 & 30 \\
\hline & $\%$ & 54.5 & 52.6 \\
\hline 3 & Foreign banks & 34 & 15 \\
\hline & $\%$ & 23.8 & 26.3 \\
\hline $\mathrm{T}$ & Total sample & 143 & 57 \\
\hline & $\%$ & 100 & 100 \\
\hline
\end{tabular}


Table 6: Description of variables

\begin{tabular}{c|l|l}
\hline Variable & \multicolumn{2}{|c}{ Description } \\
\hline$t c$ & & $\begin{array}{l}\text { Total cost : Total value of interest expenses and non } \\
\text { interest expenses }\end{array}$ \\
\hline$y_{1}$ & Output (1) & Total credits/loans \\
\hline$y_{2}$ & Output (2) & Other productive assets \\
\hline$w_{1}$ & Input (1) & $\begin{array}{l}\text { Price of labour: Total salaries and employee benefit over } \\
\text { total assets }\end{array}$ \\
\hline$w_{2}$ & Input (2) & $\begin{array}{l}\text { Price of capital: Total non interest expenses minus total } \\
\text { salaries and employee benefit over total fixed assets }\end{array}$ \\
\hline$w_{3}$ & Input (3) & $\begin{array}{l}\text { Price of funds: Total interest expenses over total funds } \\
\text { borrowed }\end{array}$ \\
\hline
\end{tabular}


Table 7: LR-tests for both countries

\begin{tabular}{c|c|c}
\hline & Indonesia & Turkey \\
\hline LR chi2(20) test & 58.75 & 255.58 \\
\hline Prob. $>$ chi2 & 0.000 & 0.000 \\
\hline
\end{tabular}


Table 8: Inefficiency scores for all samples

\begin{tabular}{|c|c|c|c|c|c|c|c|c|c|c|}
\hline $\begin{array}{c}\text { Indonesia } \\
\text { (time variant model) }\end{array}$ & \multicolumn{2}{|c|}{ Sector } & \multicolumn{2}{|c|}{ Privatly-owned } & \multicolumn{2}{|c|}{ Privatly-owned } & \multicolumn{2}{|c|}{ Privatly-owned } & \multicolumn{2}{|c|}{ State-owned } \\
\hline $\mathrm{mu}$ & 0.94 & 0.69 & 7.57 & 7.64 & 1.43 & 6.77 & 0.20 & 2.11 & -0.18 & 9.22 \\
\hline & $(1.265)$ & $(1.574)$ & $(1.405)^{* * *}$ & $(1.960)^{* * *}$ & $(1.537)$ & $(4.295)^{* *}$ & $(0.778)$ & $(0.875)^{* * *}$ & $(51.344)$ & $(5.242)^{* *}$ \\
\hline & $(0.113)^{* * *}$ & $(0.070)^{* * *}$ & $(0.049)^{* * *}$ & $(0.059)^{* * *}$ & $(0.081)$ & $(0.160)$ & (1812.988) & $(0.749)^{*}$ & $(4.025)$ & $(0.166)$ \\
\hline Observations & 919 & 438 & 848 & 570 & 594 & 158 & 234 & 66 & 234 & 61 \\
\hline Number of groups & 3 & 3 & 2 & 2 & 1 & 1 & 1 & 1 & 1 & 1 \\
\hline
\end{tabular}

\begin{tabular}{|c|c|c|c|c|c|c|c|c|c|c|}
\hline \multirow{2}{*}{$\begin{array}{c}\text { Turkey } \\
\text { (time variant model) }\end{array}$} & \multicolumn{2}{|c|}{ Sector } & \multicolumn{2}{|c|}{ Privatly-owned } & \multicolumn{2}{|c|}{$\frac{\text { Privatly-owned }}{\text { Domestic }}$} & \multicolumn{2}{|c|}{$\begin{array}{c}\text { Privatly-owned } \\
\text { Foreign }\end{array}$} & \multicolumn{2}{|c|}{ State-owned } \\
\hline & Before & בAfter & Before & After & Before & After & Before & Before & Before & After \\
\hline \multirow[t]{2}{*}{$\mathrm{mu}$} & 1.87 & 1.98 & 0.81 & 0.83 & 0.06 & 2.93 & 0.41 & 1.61 & 9.16 & ב11.95 \\
\hline & $(0.563)^{* * *}$ & $(0.459)^{* * *}$ & $(0.333)^{* * *}$ & $(0.321)^{* * *}$ & $(0.064)$ & $(0.585) * * *$ & $(0.563)$ & $(0.744)^{* *}$ & $(3.054)^{* * * *}$ & $(2.865) * * *$ \\
\hline \multirow[t]{2}{*}{ Insigma2 } & -1.91 & -2.03 & -2.06 & -2.10 & -2.92 & -2.45 & -3.36 & -2.58 & -2.19 & -2.02 \\
\hline & $(0.154)^{* * *}$ & $(0.157)^{* * *} \|$ & $(0.190)^{* * *}$ & $(0.073)^{* * *}$ & $(0.163)^{* * * *}$ & $(0.118)^{* * *}$ & $(0.198)^{* * * *}$ & $(0.171) * * * \|$ & $(0.145)^{* * * *}$ & $(0.139)^{* * *}$ \\
\hline Observations & 144 & 271 & 343 & 373 & 75 & 143 & 51 & 68 & 95 & 103 \\
\hline Number of groups & 3 & 3 & 2 & 2 & 1 & 1 & 1 & 1 & 1 & 1 \\
\hline
\end{tabular}


Table 9: Inefficiency scores for size samples

\begin{tabular}{||c||cc||cc||}
\hline \multirow{2}{*}{\begin{tabular}{c}
\multirow{2}{*}{$\begin{array}{c}\text { Indonesia } \\
\text { (time invariant model) }\end{array}$} \\
\cline { 2 - 5 }
\end{tabular}} & \multicolumn{2}{c||}{$25 \%$ largest } & \multicolumn{2}{c||}{$25 \%$ smallest } \\
\hline \hline $\mathrm{mu}$ & $\mathbf{5 e f o r e}$ & After & Before & After \\
& $(1.890)^{* * *}$ & $(1.836)^{* * *}$ & $(2.272)^{*}$ & $(1.919)$ \\
lnsigma2 & $\mathbf{2 . 6 9}$ & $\mathbf{2 . 6 8}$ & $\mathbf{2 . 7 6}$ & $\mathbf{2 . 7 8}$ \\
& $(0.122)^{* * *}$ & $(0.122)^{* * *}$ & $(0.072)^{* * *}$ & $(0.089)^{* * *}$ \\
Observations & 336 & 340 & 418 & 413 \\
Number of groups & 1 & 1 & 1 & 1 \\
\hline \hline
\end{tabular}

\begin{tabular}{||c||cc||cc||}
\hline \multirow{2}{*}{\begin{tabular}{c}
\multirow{2}{*}{$\begin{array}{c}\text { Turkey } \\
\text { (time invariant model) }\end{array}$} \\
\cline { 2 - 5 }
\end{tabular}} & \multicolumn{2}{c||}{$25 \%$ largest } & \multicolumn{2}{c||}{$25 \%$ smallest } \\
\hline \hline \multirow{2}{*}{$\mathrm{mu}$} & $\mathbf{0 . 6 8}$ & $\mathbf{0 . 6 6}$ & 0.27 & $\mathbf{0 . 2 9}$ \\
& $(0.182)^{* * *}$ & $(0.189)^{* * *}$ & $(0.172)$ & $(0.169)^{*}$ \\
lnsigma2 & $\mathbf{- 2 . 0 3}$ & $\mathbf{- 1 . 9 5}$ & $\mathbf{- 2 . 0 0}$ & $\mathbf{- 1 . 9 6}$ \\
& $(0.347)^{* * *}$ & $(0.366)^{* * *}$ & $(0.141)^{* * *}$ & $(0.152)^{* * *}$ \\
Observations & 157 & 161 & 142 & 146 \\
Number of groups & 1 & 1 & 1 & 1 \\
\hline \hline
\end{tabular}


Figure 1: Foreign direct investment, net inflows (\% of GDP) Source: World Bank

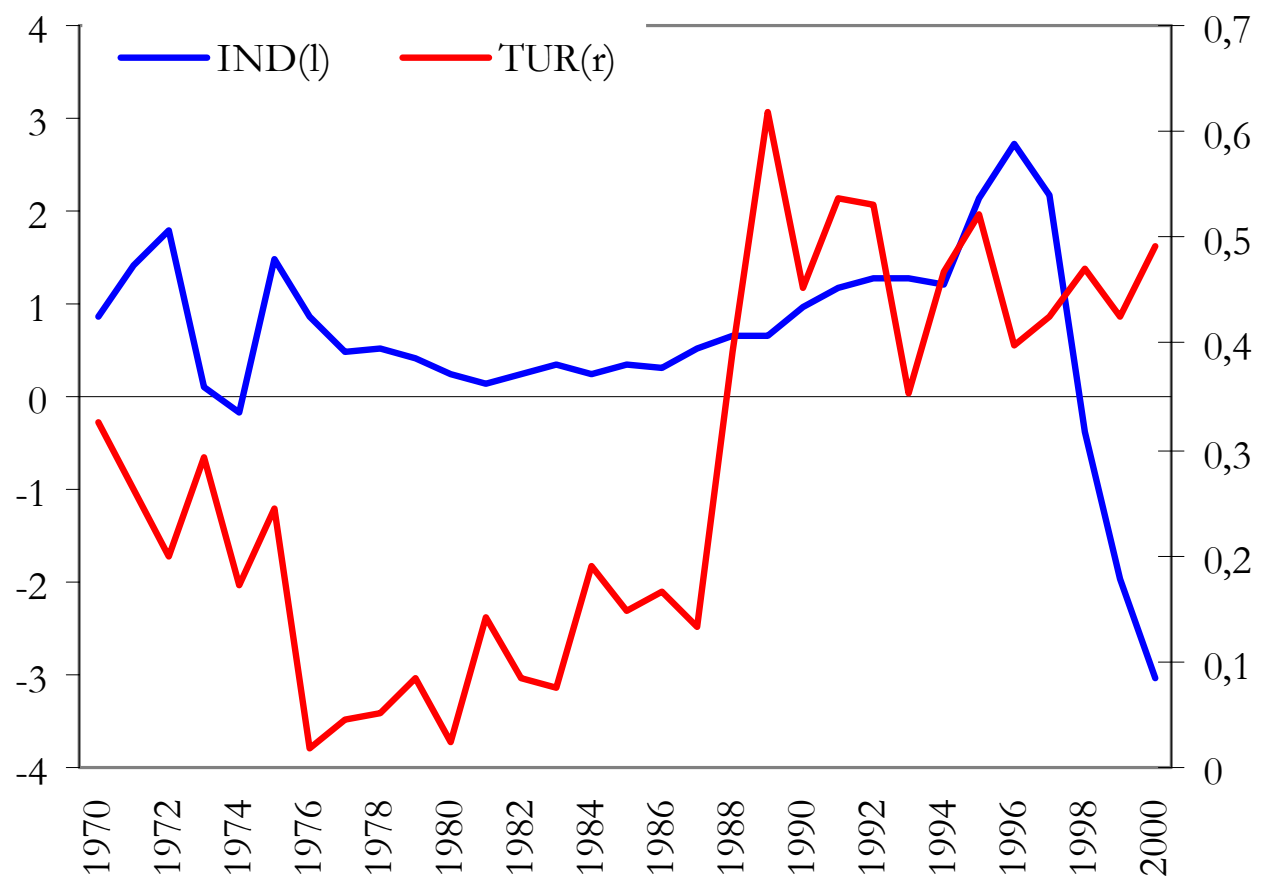


Figure 2: Net Working Capital/ Total Assets(\%)

Source: TBB (Turkey) and Ecofin and Indonesian Banking Directory (Indonesia)

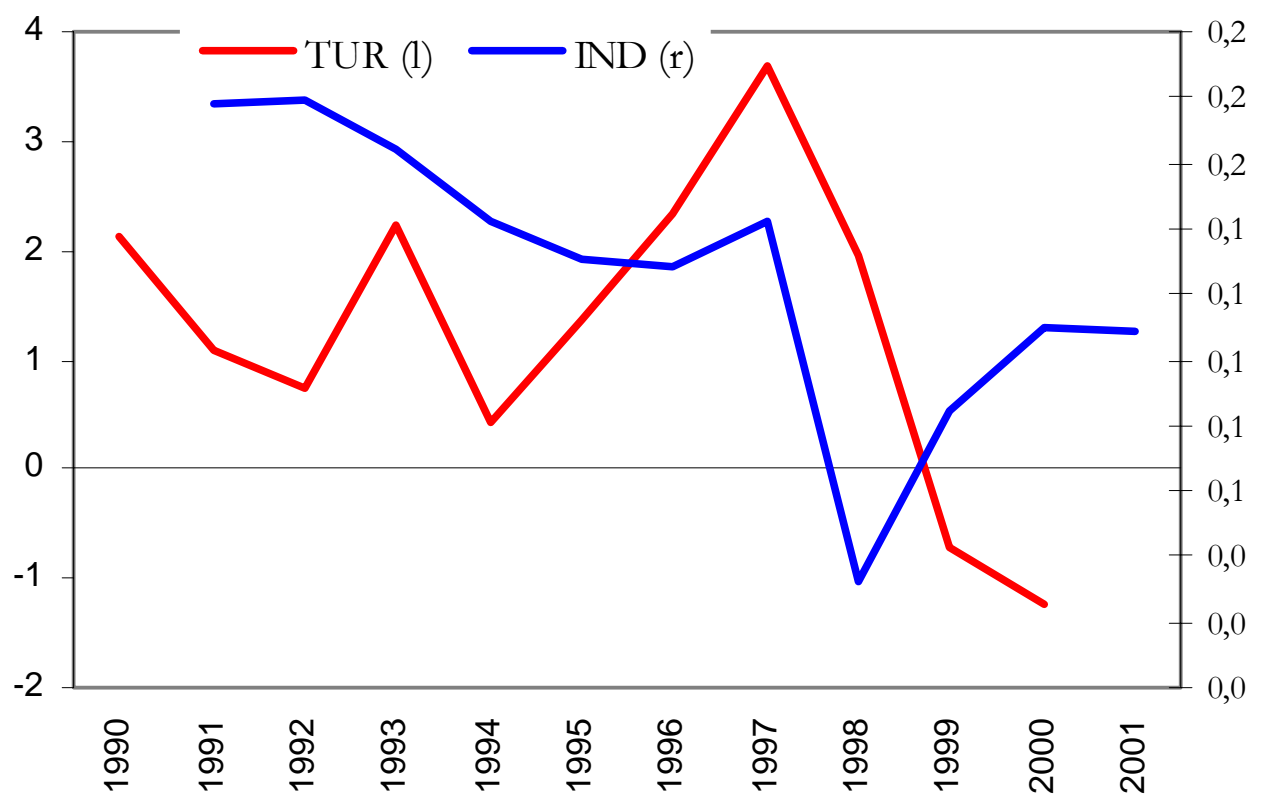


Figure 3: Permanent assets (PA)/Total assets and Non-performing loans (NPL)/Total loans Source : TBB (Turkey) and Ecofin and Indonesian Banking Directory (Indonesia)

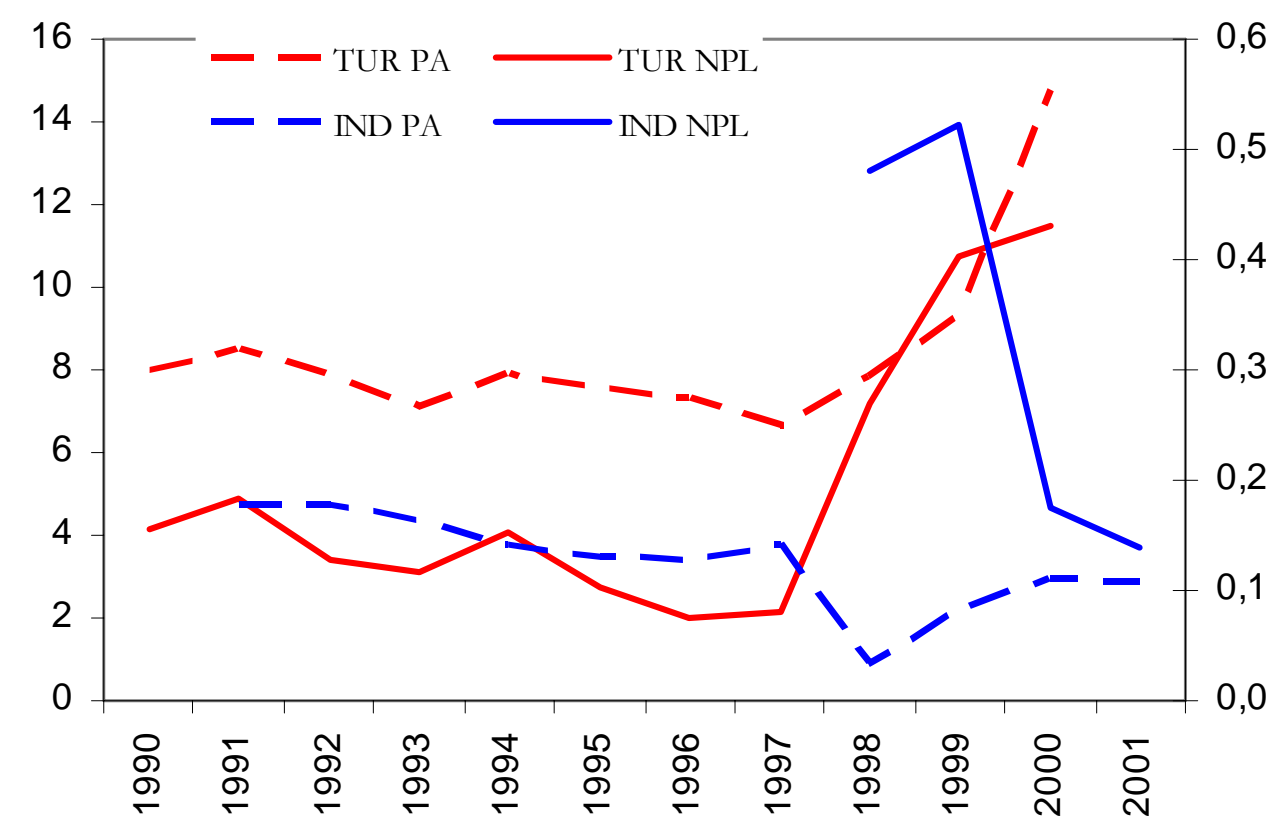


Figure 4: Liquidity ratios: Liquid Assets/Total Assets TURKEY

Source: TBB (Turkey) and Ecofin and Indonesian Banking Directory (Indonesia)

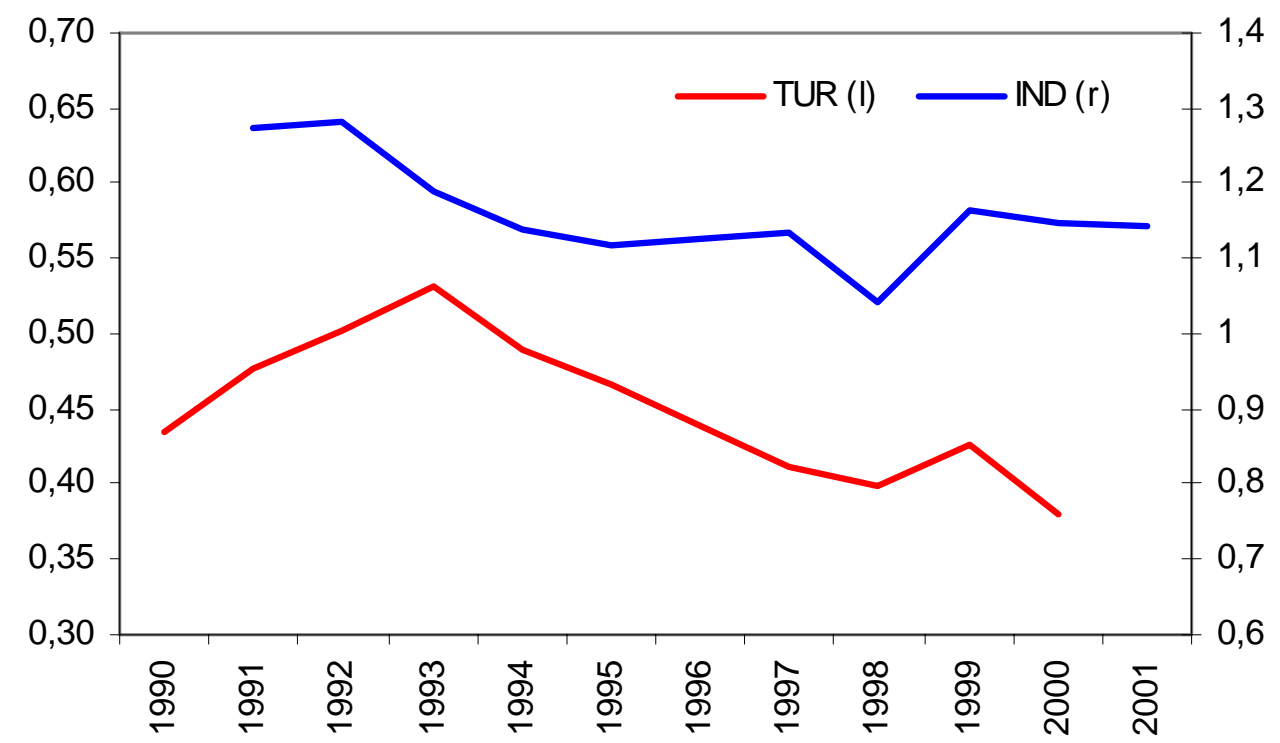


Figure 5: Profitability ratios: Non-Interest Income/Non-Interest Expenses

Source: TBB (Turkey) and Ecofin and Indonesian Banking Directory (Indonesia)

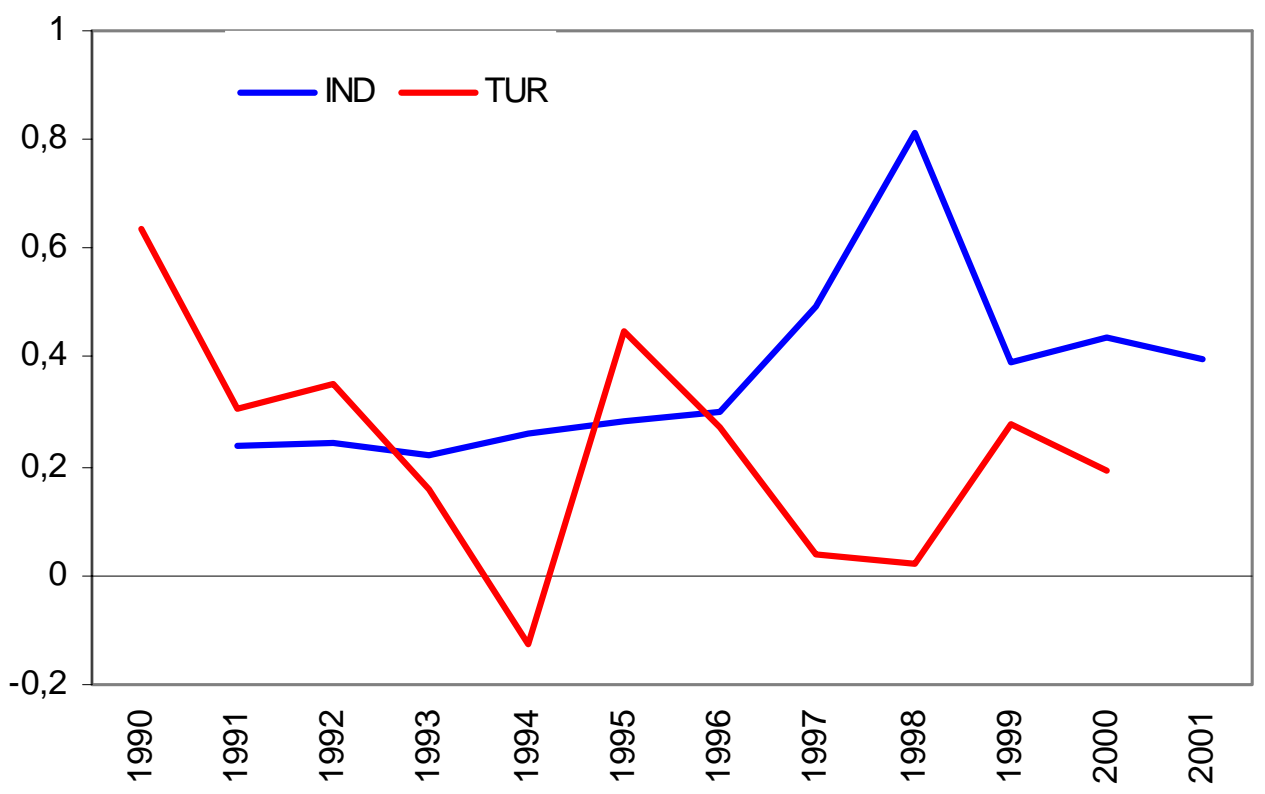

